\title{
Geastrum hirsutum or G. trichiferum (Basidiomycota, Geastraceae): which name do use?
}

\author{
Silva $\mathrm{BDB}^{1}$, Sousa $\mathrm{JO}^{1}$, Rodrigues $\mathrm{ACM}^{2}$, Bicudo $\mathrm{CEM}^{3}$, Calonge $\mathrm{FD}^{4}$ and \\ Baseia IG ${ }^{1}$ \\ ${ }^{1}$ Universidade Federal do Rio Grande do Norte, Departamento de Botânica e Zoologia, Programa de Pós-graduação \\ em Sistemática e Evolução, Campus Universitário, 59072-970, Natal, RN, Brazil \\ ${ }^{2}$ Universidade Federal de Pernambuco, Departamento de Micologia, Programa de Pós-Graduação em Biologia de \\ Fungos, Av. Nelson Chaves s/n, 50760-420, Recife, PE, Brazil \\ ${ }^{3}$ Instituto de Botânica, Caixa Postal 68041, 04045-972, São Paulo, SP, Brazil \\ ${ }^{4}$ Real Jardín Botánico, CSIC Plaza de Murillo 2, 28014, Madrid, Spain
}

Silva BDB, Sousa JO, Rodrigues ACM, Bicudo CEM, Calonge FD, Baseia IG 2015 - Geastrum hirsutum or G. trichiferum (Basidiomycota, Geastraceae): which name do use? Mycosphere 6(4), 459-462, Doi 10.5943/mycosphere/6/4/7

\begin{abstract}
Geastrum hirsutum was described in 2006 and synonymized with G. trichiferum in 2012. Reevaluating the nomenclature and the typification of the two Geastrum species, it was found that G. trichiferum cannot be used since its basionym Geaster trichifer is a nomen nudum as it was published without description or reference to a previous effectively published description. Attempting to validate the name $G$. trichifer, a lectotypification was made in 2012, which does not resolve G. trichifer's situation, since $G$. hirsutum has publication date priority over the lectotypification. As a nomen nudum, Geastrum trichiferum becomes unavailable and can no longer be used, since it was not validly published.
\end{abstract}

Key words - earthstars - gasteromycetes - nomenclature - taxonomy - typus

\section{Introduction}

Geastrum Persoon has been somewhat well studied in Brazil during recent years (Baseia et al. 2006, Baseia \& Calonge 2006, Leite et al. 2007, 2011, Cortez et al. 2008, Fazolino et al. 2008, Trierveiler-Pereira et al. 2011, Silva et al. 2011, 2013, Cabral et al. 2014a, 2014b, Sousa et al. 2014a, 2014b, 2014c). Moreover, some species need to be revised although some current herbarium exsiccatae are not kept in suitable storage conditions to be studied. For Geastrum, it is imperative that collection specimen has mature basidiomata, and that the essential identification characters are easily visible such as form and delimitation of the peristome, mycelial layer and presence of gleba for analysis of the basidiospores and capillitium (Zamora et al. 2014).

Geastrum hirsutum Baseia \& Calonge was protologued in 2006, characterized by the development of the subiculum, exoperidium with hairy mycelial layer, hairs $1.5-3 \mathrm{~mm}$ tall, delimited peristome, small basidiospores $(2.5-3 \mu \mathrm{m})$ and as inhabitants of wood, termite mounds and leaf-litter (Baseia \& Calonge 2006). In 2012, the species was synonymized with Geastrum trichiferum Rick due to similar characteristics (Trierveiler-Pereira \& Silveira 2012). 


\section{Historical of the designations of Geaster trichifer}

Lloyd (1907) used the name Geaster trichifer Rick for the first time together with an illustration of its basidiome and its comparison with $G$. mirabilis Mont., considering that $G$. trichifer exoperidium is more strigose than that of G. mirabilis. In his analysis, Lloyd (1907) also alleged that G. trichifer was similar to G. lignicola Berk. Lloyd (1907) did not include a description or a good picture of $G$. trichifer.

Saccardo \& Trotter (1912) cited G. mirabilis with two varieties, G. mirabilis var. subiculosus (Cooke \& Massee) Lloyd and G. mirabilis var. trichifer (Rick) Sacc. \& Trotter, differing them by the larger and clearer basidiomata in G. mirabilis var. subiculosus, and the strongly strigose exoperidium in G. mirabilis var. trichifer. Gibbs (1916) also considered G. mirabilis var. trichifer, whereas Lloyd (1918), Coker \& Couch (1928) and Dennis (1953) considered the two varieties to be separate species, differentiating G. mirabilis from G. trichifer by using the same characteristics cited by Lloyd (1907), however, adding the color and the size of the exoperidium hairs, as well as the diameter of basidiospores $(3-3.6 \mu \mathrm{m})$.

Rick (1928), in a mycological summary for the State of Rio Grande do Sul, southern Brazil, listed the new taxa that were examined and included the location of the type-species and the journal in which they were published. In this list, it was indicated that Lloyd (1907) was the first to publish G. trichifer, thus agreeing with Lloyd (1925). Later on, G. trichifer was again mentioned for the same location (Rick 1930, 1961).

Ponce de Leon (1968), in a review of the family Geastraceae, included G. trichifer and $G$. mirabilis in the synonymy of Geastrum schweinitzii (Berk. \& M.A. Curtis) Zeller. TrierveilerPereira \& Silveira (2012) lectotypified Geaster trichifer in Geastrum trichiferum and synonymized $G$. hirsutum with $G$. trichiferum, concluding that both presented the same morphological characteristics.

\section{Results and discussion}

The original publication of Geaster trichifer (= Geastrum trichiferum) in Lloyd (1907) did not include a description, nor designated the type or any indication that the referred species was new. According to the Melbourne Code, in the Art. 38.7 and 38.9 (McNeill et al. 2012), prior to 1st January 1908 a name is valid if there is an illustration with analysis that helps in the identification of the species. Based on this information, G. trichifer should be considered a nomen nudum, since the original illustration does not provide sufficient information for its perfect and unequivocal identification.

In the first publication of this species, only illustrations (p. 314, fig. 147 and 148) complemented by a succinct comment are presented, mentioning that the species exhibits a strongly strigose exoperidium. In the legend of the figures, the species is only identified as Geaster sp., and throughout the comments it was reported that the species was named G. trichifer by Rick. In accordance to the taxonomical studies on the genus Geastrum, the strongly strigose exoperidium alone does not enable the specimen to be identified at the species level, considering that other species in the genus do show this characteristic, as Geastrum albonigrum Calonge \& M. Mata (Calonge \& Mata 2004) and G. inpaense T.S. Cabral, B.D.B. Silva \& I.G. Baseia (Cabral et al. 2014a).

A lectotypification was recently made by Trierveiler-Pereira \& Silveira (2012) in an attempt to maintain the name 'G. trichiferum'. Geastrum trichiferum's situation was, however, not decided, since $G$. hirsutum has priority over the lectotypification carried out, due to the publication date. Therefore, it is our conclusion that G. trichifer is a nomen nudum and consequently unavailable, i.e. no longer able to be used since it was never published and the lectotypification carried out in 2012 has no effect. To date, G. hirsutum is the only name to be considered. 


\section{Acknowledgements}

The authors are grateful the Coordenação de Aperfeiçoamento de Pessoal de Nível Superior (CAPES) and Conselho Nacional de Desenvolvimento Científico e Tecnológico (CNPq) for providing the scholarships.

\section{References}

Baseia IG, Calonge FD. 2006 - Geastrum hirsutum: a new earthstar fungus with a hairy exoperidium. Mycotaxon 95, 301-304.

Baseia IG, Maia LC, Calonge FD. 2006 - Notes on Phallales in the Neotropics. Boletín de la Sociedad Micologica de Madrid 30, 87-93.

Cabral TS, Silva BDB, Ishikawa NK, Alfredo DS, Braga-Neto, R., Clement, CR, Baseia IG. 2014a - A new species and new records of gasteroid fungi (Basidiomycota) from Central Amazonia, Brazil. Phytotaxa 183 (4), 239-253.

Cabral TS, Silva BDB, Marinho P, Baseia IG. 2014b - Geastrum rusticum (Geastraceae, Basidiomycota), a new earthstar fungus in the Brazilian Atlantic rainforest - a molecular analysis. Nova Hedwigia 98 (1-2), 265-272.

Calonge FD, Mata M. 2004 - A new species of Geastrum from Costa Rica and México. Boletín de la Sociedad Micologica de Madrid 28, 331-335.

Coker WC, Couch JN. 1928 - The Gasteromycetes of the Eastern United States and Canada. Chapel Hill The University of North Carolina Press. Baltimore: Waverly Press. http://dx.doi.org/10.5962/bhl.title.5712

Cortez VG, Baseia IG, Silveira RMB. 2008 - Gasteromicetos (Basidiomycota) no Parque Estadual de Itapuã, Viamão, Rio Grande do Sul, Brasil. Revista Brasileira de Biociências 6, 291-299.

Dennis RWG. 1953 - Some West Indian Gasteromycetes. Kew Bulletin 8(3), 307-328. http://dx.doi.org/10.2307/4115517

Fazolino EP, Calonge FD, Baseia IG. 2008 - Geastrum entomophilum, a new earthstars with an unusual spore dispersal strategy. Mycotaxon 104, 449-453.

Gibbs LS. 1916 - Dutch N.W. New Guinea: a contribution to the phytogeography and flora of the Arfak mountains. London: Taylor and Francis.

Leite AG, Calonge FD, Baseia IG. 2007 - Additional studies on Geastrum from Northeastern Brazil. Mycotaxon 101,103-111.

Leite AG, Assis HK, Silva BDB, Sotão HMP, Baseia IG. 2011 - Geastrum species from the Amazon Forest, Brazil. Mycotaxon 118, 383-392.

Lloyd GC. 1907 - New notes on the Geasters. Mycological Notes no. 25. Mycological Writings 2, 309-317.

Lloyd GC. 1918 - Rare or interesting fungi received from correspondents. Mycological Notes no. 56. Mycological Writings 5, 800-812.

Lloyd GC. 1925 - Notes on specimens received. Mycological Notes no. 74. Mycological Writings 7, 1348.

McNeill J, Barrie FR, Buck WR, Demoulin V, Greuter W, Hawksworth DL, Herendeen PS, Knapp S, Marhold K, Prado J, Prud'homme van Reine WF, Smith GF, Wiersema JH, Turland NJ (eds.). 2012 - International Code of Nomenclature for algae, fungi, and plants (Melbourne Code): Adopted by the Eighteenth International Botanical Congress Melbourne, Australia, July 2011. Regnum Vegetabile 154. Königstein: Koeltz Scientific Books.

Ponce de Leon P. 1968 - A revision of the Geastraceae. Fieldiana Botany 31, 303-349.

Rick J. 1928 - Resumo mycologico. Egatea 13, 432-439.

Rick J. 1930 - Lycoperdineas riograndenses. Egatea 15, 222-230.

Rick J. 1961 - Basidiomycetes Eubasidii no Rio Grande do Sul, Brasilia. Iheringia 9, 451-480. 
Saccardo PA, Trotter A. 1912 - Supplementum Universale. Pars VIII. HymenomycetaePhycomycetae. Sylloge Fungorum 21, 1-923.

Silva BDB, Cabral TS, Marinho P, Ishikawa NK, Baseia IG. 2013 - Two new species of Geastrum (Basidiomycota) found in Brazil. Nova Hedwigia 96 (3-4), 445-456.

Silva BDB, Sousa JO, Baseia IG. 2011 - Discovery of Geastrum xerophilum from the Neotropics. Mycotaxon 118, 355-359.

Sousa JO, Morais LA, Nascimento YM, Baseia IG. 2014a - Updates on the geographic distribution of three Geastrum species from Brazilian semi-arid region. Mycosphere 3, 467-474.

Sousa JO, Silva BDB, Alfredo DS, Baseia IG. 2014b - New records of Geastraceae (Basidiomycota: Phallomycetidae) from Atlantic Rainforest Remmants and Relicts of Northeastern Brazil. Darwiniana Nueva Serie 2 (2), 207-221.

Sousa JO, Silva BDB, Baseia IG. 2014c - Geastrum from the Atlantic Forest in northeast Brazil new records for Brazil. Mycotaxon 129, 169-179.

Trierveiler-Pereira L, Calonge FD, Baseia IG. 2011 - New distributional data on Geastrum (Geastraceae, Basidiomycota) from Brazil. Acta Botanica Brasilica 25, 577-585.

Trierveiler-Pereira L, Silveira RMB. 2012 - On the Geastrum species (Geastraceae, Basidiomycota) described by Rick. Phytotaxa 61, 37-46.

Zamora JC, Calonge FD, Hosaka K, Martín MPM. 2014 - Systematics of the genus Geastrum (Fungi: Basidiomycota) revisited. Systematics and Phylogeny. Taxon 63(3), 447-497. 